\title{
Training of nursing students in integrated care for the elderly
}

\author{
Wanderson Carneiro Moreira, ${ }^{12}$ \\ Ana Raquel Batista de Carvalho² \\ Eliana Campêlo Lago² \\ Fernanda Cláudia Miranda Amorim, ${ }^{12}$ \\ Delmo de Carvalho Alencar ${ }^{3}$ \\ Camila Aparecida Pinheiro Landim Almeida²
}

Abstract

Objective: To analyze training in integrated health care for the elderly from the perspective of nursing students. Method: A descriptive and exploratory study with a qualitative approach was carried out using the action research method with the participation of 24 nursing students from a university center in Piauí, Brazil. Data were obtained through semi-structured interviews and submitted to content analysis. Results: Two thematic categories emerged: Perspectives on aging, violence and sexuality and $A$ bolistic approach to the elderly: integrating training and care. Conclusion: The perspective of the students on integrated care for the elderly is fragmented, stemming from the limitations of the training process for such care.
Keywords: Elderly. Nursing. Integrality in Health.

Education, Nursing.

Universidade do Vale do Paraíba, Instituto de Pesquisa e Desenvolvimento, Programa de Pós-graduação em Engenharia Biomédica. São José dos Campos, São Paulo, Brasil.

2 Centro Universitário UNINOVAFAPI, Departamento de Enfermagem, Programa de Pós-graduação em Saúde da Família. Teresina, Piauí, Brasil.

3 Universidade Federal do Piauí, Centro de Ciências da Saúde, Programa de Pós-graduação em Enfermagem. Teresina, Piauí, Brasil.

Research funding: National Council for Scientific and Technological Development (CNPq) and Ministry of Science and Technology (MCT). Scientific Initiation Scholarship Program, $\mathrm{n}^{\circ}$ 142706/2016-7.

Correspondence

Wanderson Carneiro Moreira

wandersoncm@univap.br 


\section{INTRODUCTION}

The quantitative increase in the number of elderly people presents major challenges to public health, requiring public policy interventions to address the needs of the population ${ }^{1}$. The issue is a priority for nursing science, justifying research that helps improve the quality of life of the elderly.

The initial training of nurses plays a key part in this process due to its significance for future actions and the construction of the skills necessary for the efficient performance of the role. This training should seek to meet the new paradigms of care, in which students comprehend the human being in an integrated manner, establishing contact with the social environment, as well as recognizing themselves as a subject in the process of training people, providing a range of knowledge for the criteria of a broad, complex and socially conscious education ${ }^{2}$.

However, even though the skills and abilities necessary for integrated and humanitarian care are indispensable in the training of nurses, studies have identified a lack of preparation for action from the perspective of integrated health care ${ }^{3}$. As important as the training of students is the need to address the situations of professionals already active in the labor market, minimizing the effects of their inadequate training and seeking ways to ensure that their working practices meet the challenges posed for the implementation of the Unified Health System, especially in the area of primary health care ${ }^{4,5}$.

The nursing student should therefore understand all the phenomena and vulnerabilities related to the elderly, with an emphasis on violence and sexuality, which can significantly influence and affect the life of these individuals.

However, the discussions about sexuality and violence related to the elderly during nursing training does not take into account the scale of the issue in society in recent years, due to reduced timetables which do not allow the nurse to provide qualified and grounded care in the prevention and promotion of health.

The present study therefore attempts to address the gaps in training regarding the aging process and its repercussions for health care. Its relevance is amplified when we consider the growing demand for professionals with suitable training to attend the elderly segment, coupled with the lack of professionals with such training.

To guide the study the following research question was chosen: are nursing students adequately trained in integrated health care for the elderly? Based on this question, the objective was to analyze training in the integrated health care of the elderly from the perspective of nursing students.

\section{METHOD}

A descriptive and exploratory study with a qualitative approach was carried out in a University Center located in a state capital of the northeast region of Brazil. Twenty-four students from the undergraduate nursing course were selected due to being correctly enrolled in the institution and attending the Elderly Health module. All students under the age of 18 who were on health leave during the period of data collection were excluded.

The context of the problem was surveyed prior to data collection, with the intention of identifying emerging issues and themes in the curriculum from the perspective of the nursing students themselves. This meeting took place in the university center with the presence of researchers and students who discussed the teaching plan of the elderly health subject offered in the nursing course of the institution. At the end of the meeting, it was concluded in consensus that the content on violence and sexuality needed to be broadened in order to prepare the student for the integrated care of the elderly.

The discipline mentioned is offered by the institution in the seventh period of the undergraduate nursing course with a timetable of 80 class hours. The teaching plan of the course includes contents aimed at the care of the elderly in the health-disease process, focused on the diagnosis, planning and evaluation of nursing care at the levels of prevention, promotion, rehabilitation and rehabilitation of the individual.

After this stage data were collected between May and June of 2016 through the action research methodology, which was chosen as it allows knowledge to be generated, experiences to be 
obtained, contributions to be made to the discussion and the debate on the issues addressed to be extended ${ }^{6}$. At this stage, the students were invited to participate in the investigation. Once they had accepted they were informed about the study and a Free and Informed Consent Form was read and signed by all the participants. The researchers then conducted three thematic seminars which took place during the last theoretical meetings of the discipline. Each seminar lasted an average of one hour and thirty minutes and the themes were planned based on the main focus of the research so that the objectives of the study were achieved and a contribution to the training of future nurses was ensured through the methodology applied.

After the seminars, interviews were recorded at a private site using a semi-structured thematic guide to collect information, guided by the following questions: What is your view on aging? What is the meaning of violence against the elderly for you? How do you treat the sexuality of the elderly? What is the importance of your training in terms of intervening and providing integrated care in relation to the mentioned phenomena? The interview is one of the techniques most used in studies with qualitative approaches, from the collection of information to verbal communication?

The data produced were transcribed in full and analyzed by the Content Analysis Technique, which is based on three stages: pre-analysis, material exploration, data processing and inference of the results ${ }^{8}$.

The results show the excerpts from the reports. As a way of preserving anonymity, "S" was added, which represents "student", and a number that indicates the sequence of the interview conducted: (S1), (S2), (S3).

This study is part of the research project "Training of the nursing student for the integrated care of the elderly in the light of social representations" and was approved by a research bid invitation and funded by the National Council for Research and Technological Development (CNPq). The development of the study met the national and international norms of ethics in research involving human beings, according to the Research Ethics Committee, under approval $\mathrm{n}^{\circ}$ 1.541.127.

\section{RESULTS}

Of the 24 participants in the survey 18 were women and the mean age was 23 years. All were enrolled in the health of the elderly discipline, and most did not participate in any university extension project with a thematic approach.

The analysis of the content of the speeches that emerged from the interviews resulted in the identification of two thematic categories: Perspectives on aging, violence and sexuality and a Holistic approach to the elderly: integrating training and care.

\section{Perspectives on aging, violence and sexuality}

During the interviews, students referred to aging as a natural condition that results in physical and social changes for the elderly. They also reflected that this event represents a major achievement, that the health sector is responsible for providing quality of life to this population, and that the academy should encourage students and promote training to improve care:

"Old age is a great achievement, it is an inevitable process and inherent in the human will, it is part of the biological cycle and has repercussions on the functional and physiological capacity of the body" (S2).

"[...] It is a phase of life with many physical and social changes that occurs when you have a lot of experience" (S10).

"The elderly need special health care, we need to understand the physiological process of old age, diseases and other common factors of this phase" (S20).

"[...] it is very important that the professional is adequately trained to provide quality nursing care" (S23).

Regarding violence against the elderly, participants reported that this occurs due to the increase in the number of elderly people, and that they are vulnerable to abuse, meaning attention and care is required to defend this population. They demonstrated that there are gaps in the training process, and that the undergraduate course should devote more time to 
training in this area, in order to enable nurses to dispense the quality care and assistance:

"[...] violence is very common, we have to be alert to it" (S11).

“[...] I Know victims of violence, it's sad. I think the situation is getting worse because there are more old people, so the violence grows as well" (S15).

"It's a major problem, especially in health, as is as the cost of special care" (S22).

"Our course should talk more about this, it could fit in a number of disciplines, I think it's important, you never know when you're going to come across it, we should study it more" (S7).

They said that the sexuality of the elderly is something negative and labeled with stereotypes. Their statements also infer the difficulty in approaching the subject with the elderly, a reflection of the culture in which older persons are seen as being asexual and of training that is lacking in terms of approaching sexuality during the undergraduate course, thus precluding the acquisition of complete understanding of the subject by the student:

"[...] the elderly have no sex life, we need to inform them about the risk they are exposed to and seek to educate them about sexuality" (S1).

"[...] a lack of information, the subject isn't really dealt with, I believe it will be difficult for me to deal with and I think it should be studied more" (S21).

"[...] it can make people uncomfortable" (S17).

"[...] the knowledge we acquire on the undergraduate course isn't enough" (S18).

\section{A holistic approach to the elderly: integrating training and care}

This category contains information on the integrated care of the elderly. The participants showed that it is extremely important to understand the aspects that permeate aging, above all sexuality, in a way that is capable of providing a holistic approach to the health care of the elderly, but also revealed that these subjects are insufficiently addressed in vocational training.

"[...] the knowledge that we acquire about violence is very important, as we need this to care for the elderly in a broad way" (S10).

"[...] sexuality also covers the need to express and receive affection, not just the sexual act" (S9).

"It is very important to deal with sexuality in the life of the elderly, because they need affection, everyone needs it, from hugs, kisses" (S7).

"[...] think that this part should be more addressed more, this topic should be explored with seminars and lectures during the course" (S16).

“[...] the undergraduate course doesn't deal with this subject, as it was hardly debated at all in my training" (S17).

Thus, the statements reveal that the graduate course has an important role in the training of students, so that they acquire the knowledge, skills and competences necessary for the integrated care of the elderly:

"[...] it is very important that the professional is adequately trained to provide quality nursing care" (S3).

"[...] we can care for them with better knowledge $[\ldots] "(\mathrm{~S} 13)$.

"[...] knowledge about these issues is important, as the elderly population is growing, we need to acquire skills" (S2).

"[...] training is extremely important for the care of the elderly" (S8).

\section{DISCUSSION}

Understanding the perspective of undergraduate students in nursing on aspects relating to aging is of fundamental importance in the context of academic training, as such knowledge allows the highlighting of key elements in the reality of this 
group and contributing to change in this scenario. By understanding these perspectives, it is possible to express the most suitable way of acting with elderly people who need integrated and humanized attention.

In this study, students described the same perception described in the literature, in which aging or may not be associated with the establishment and accumulation of diseases. It cannot, however, be seen only as a disease, but a stage of life with its own characteristics and values, in which changes occur in the individual, in terms of their bodily structure, their metabolism, their biochemical balance, their immune system, their nutrition, their mechanical functions and their emotional, intellectual and communicative conditions $^{9,10}$.

It is understood that the change in the age pyramid in Brazil means that vocational health training should enable the student to understand and attend to the specific needs of the elderly, as population aging is a global reality that demands effective interventions to ensure the senescence of the population ${ }^{11-13}$.

Health promotion and primary and secondary prevention of diseases in old age are the most cost-effective ways of achieving the reduction of morbidity. The importance of training health professionals, however, should be emphasized in undergraduate and continuing education courses ${ }^{14}$.

In undergraduate courses, disciplines are offered that address the health of the elderly, but there is a concentration of contents centered on the biomedical model $^{12}$.

Dispensing comprehensive care for the elderly does not only involve healing and rehabilitation, but especially in primary care, involves other aspects that must be attended to. When asked about the demands of elderly care, students in the present study referred to violence and sexuality as aspects that need attention. They considered that exposure to violence was due to vulnerability caused by age and represented the elderly as asexual, with this representation reflecting on the social and cultural aspects determined by society. They described the limitations in their academic training, as little is discussed about sexuality and

violence against the elderly in their course, hindering integrated care in these aspects.

Studies state that during their undergraduate course, students are not encouraged to apply specific knowledge and concepts related to the integrated health of the elderly in their care dynamics. It is therefore important to develop academic activities that not only inform the students about aging, but also train professionals capable of respecting the limits and peculiarities of this stage of life, allowing them to recognize the physical, emotional and social changes of the elderly ${ }^{14}$.

The importance of providing academic training based on integrality and interdisciplinarity is therefore highlighted. This will allow the construction of questioning and participative care within public health policies, using the knowledge learnt on the undergraduate course to support the well-being of the population, establishing a dialogue between the diversity of knowledges that students encounter in daily life ${ }^{15}$.

The National Curricular Guidelines of the undergraduate nursing course currently emphasize that nurses must be able to intervene on problems that influence the health-disease process, identifying health risk factors and promoting the holistic care of the human being, including in the mental health field ${ }^{16}$.

However, the existence of these guidelines does not guarantee, in practice, an integrated service for the elderly. This fact can be observed in some realities of the Family Health Strategy, in which care for the elderly refers to reductionist actions, focused on diseases such as hypertension and diabetes, and does not consider other dimensions such as sexuality ${ }^{17,18}$.

Stereotypes associated with aging and the elderly are commonly addressed in the literature. They are symbolic representations that, mainly due to the lack of knowledge regarding the phenomenon of aging, are generally manifested in a negative manner by society and substantially limit the understanding of the aging process, simultaneously contributing to building and maintaining representations, stereotypes and the myths regarding the elderly. In this sense, behaviors expected by society are strongly influenced by media, 
television, print or digital vehicles that could transmit more positive models of old age, with the intention of reducing stereotypes and prejudices ${ }^{19}$.

In this sociocultural scenario of prejudice related to the process of aging, there is another taboo issue: sexuality in old age. This is often treated as inappropriate, based on the stereotype that the elderly are devoid of sexual desire and practices, with men labeled as impotent and women as devoid of physical attraction. Coupled with this idea, some elderly people cannot exercise their sexuality without taboos. They are often resistant to the use of condoms and can even renounce and hide their sexuality so as not to feel discriminated against ${ }^{18,20}$.

The attitudes that we adopt towards the elderly and the way we relate to them directly conditions the way they view old age and the whole process of aging. In this manner, if we have positive and stimulating attitudes, we will encourage their integration into society, while negative attitudes can contribute to their discomfort and the feeling of being a burden upon others.

Regarding violence against the elderly, a study of print media, social representations and violence against the elderly shows that the construction of social representations of violence, mistreatment and neglect of the elderly is anchored in the achievements obtained by this population, governed by the Statute of the Elderly. These gains were objectified in the social actions of political power, in the dictates of science, in the dimensions of violent acts and in the achievements, defense and care of the elderly ${ }^{21}$.

Regarding the care given to these elderly people, a study reveals significant weaknesses in the implementation of public policies for the elderly, with some health professionals considering themselves as not being responsible for the listening, support, care and guidance of elderly persons with a history of violence; believing that they should only act on physical injuries and let their colleagues, psychologists and social workers, respond to the situation of violence $\mathrm{e}^{22,23}$.
In literature, there are few research studies on how future health professionals, namely university students, consider sexuality in old age. The data are focused on professionals or the elderly, dealing with the main aspects of epidemiology, perceptions of the sexuality of the elderly and the early diagnosis of HIV in the elderly population ${ }^{24}$.

The investigation of the knowledge and attitudes of students of health in relation to sexuality in old age is relevant and is based on the need to think about the broader training of these future professionals for care in different areas. Often, due to the lack of reflection on the practices and multidimensional nature of aging, these students graduate with somewhat misrepresented notions, which will lead them to consider the elderly as a homogeneous category, generalize about their physical and cognitive capacity, and apply the inappropriate use of instruments, instructions and equipment during the performance of their professional duties.

The limitations of this study include the restriction of the number of participants and of scenarios applied, which limits the scope of the results to the reality of the participants and their sample, composed only of a higher education institution, thus preventing the generalization of the results.

\section{CONCLUSION}

The study revealed that nursing students consider aging, violence and sexuality as aspects that integrate the daily life of the elderly, with a significant impact on the quality of life of this population. Limitations were observed in the training process of care for the elderly, leading to repercussions for the integrated care of the graduating students.

It is believed that this study allows for discussions and reflections on nursing training courses, creating a space of interface between health and education by uniting theoretical and practical elements of nursing knowledge relating to gerontology and geriatrics, resulting in suitable training for professionals. 


\section{REFERENCES}

1. Clegg A, Young J, Iliffe S, Rikkert MO, Rockwood K. Frailty in elderly people. Lancet. 2013;381(9868):752-62.

2. Oliveira ALB, Dourado MB, Menezes TMO. Perception of nursing undergraduate students on self-aging. Rev Bras Enferm [Internet]. 2015 [acesso em 27 set. 2017];68(2):278-83. Disponível em: http://www.scielo.br/pdf/reben/v68n2/0034-7167reben-68-02-0278.pdf

3. Craveiro IMR, Hortale VA, Oliveira APC, Dussault G. Desigualdades sociais, políticas de saúde e formação de médicos, enfermeiros e dentistas no Brasil e em Portugal. Ciênc Saúde Coletiva. 2015;20(10):2985-98.

4. Carvalho CRA, Hennington EA. A abordagem do envelhecimento na formação universitária dos profissionais de saúde: uma revisão integrativa. Rev Bras Geriatr Gerontol [Internet]. 2015 [acesso em 27 set. 2017];18(2):417-31. Disponível em: http://www.scielo.br/pdf/rbgg/v18n2/1809-9823rbgg-18-02-00417.pdf

5. Alves VP, Gomes L, Mendes GS, Valadares MO. Scientific production in pos-graduated stricto sensu Gerontology Programme at Catholic University of Brasilia in its 12 years of existence. Pan Am J Aging Res. 2015;2(2):61-6.

6. Thiollent M. Metodologia da pesquisa-ação. $18^{\mathrm{a}}$ ed. São Paulo: Cortez; 2011.

7. Minayo MCS. Pesquisa social: teoria, método e criatividade. $27^{\mathrm{a}}$ ed. Petrópolis: Vozes; 2008.

8. Bardin L. Análise de conteúdo. Lisboa: Edições 70; 2011.

9. Schimidt TCG, Silva MJP. Percepção e compreensão de profissionais e graduandos de saúde sobre o idoso e o envelhecimento humano. Rev Esc Enferm USP. 2012;46(3):612-7.

10. Oliveira ALB, Dourado MB, Menezes TMO. Undergraduate nursing students' perceptions of aging. Rev Enferm UERJ [Internet]. 2014 [acesso em 27 Set. 2017];22(5):680-5.Disponível em: http://www.facenf. uerj.br/v22n5/v22n5a16.pdf

11. Bandeira VAC, Oliveira KR, Berlezi EM. Programa de atenção ao idoso: a extensão universitária como ferramenta na formação interdisciplinar de profissionais de saúde. Cataventos. 2014;6(1):176-91.

12. Andrade ATS, Sampaio SPS, Gois CFL, Mattos MCT, Aguiar MPC, Resende GGS, et al. O ensino da enfermagem geronto geriátrica nas universidades federais brasileiras. Enferm Foco [Internet]. 2013 [acesso em 27 set. 2017];4(1):19-23. Disponível em: http://revista.cofen.gov.br/index.php/enfermagem/ article/view/496/186
13. Almeida CAPL, Silva FNO, Souza VAS, Santos VO, Lago EC, Moreira WC. Meanings attributed by health professionals to the aging process of institutionalized elderly people. Rev Rene [Internet]. 2017 [acesso em 08 nov. 2017];18(05):639-46. Disponível em: http:// www.revistarene.ufc.br/revista/index.php/revista/ article/view/2912/pdf

14. Grave MQ, Rocha CF, Périco E. A formação do profissional fisioterapeuta na atenção à saúde do idoso: uma revisão integrativa. Rev Bras Ciênc Envelhec Hum [Internet]. 2013 [acesso em 27 set. 17];9(3):100-10. Disponível em: http://seer.upf.br/ index.php/rbceh/article/view/2295/pdf

15. Sampaio W, Teixeira LT, Costa MC, Lombardo GL. Atuação do acadêmico de enfermagem num grupo da terceira idade: um relato de experiência. Rev Pesqui Cuid Fundam (Online) [Internet]. 2010 [acesso em 27 set. 2017];2(Supl.):778-80. Disponível em: http:// www.seer.unirio.br/index.php/cuidadofundamental/ article/view/1129/pdf_281

16. Brasil. Ministério da Educação. Resolução CNE/ CES no 03 de 07 de novembro de 2001. Institui as diretrizes curriculares nacionais do curso de graduação em Enfermagem. Brasília: Ministério da Educação; 2001.

17. Castro SFF, Nascimento BG, Soares SD, Barros Júnior FO, Sousa CMM, Lago EC. Sexualidade na terceira idade: a percepção do enfermeiro da estratégia saúde da família. Rev Enferm UFPE on line [Internet]. 2013 [acesso em 20 jul. 2016];7(10):5907-14. Disponível em: https:// periodicos.ufpe.br/revistas/revistaenfermagem/ article/viewFile/12216/14807.

18. Moreira WC, Lago EC, Viana MRP, Carvalho ARB, Frota BC, Pereira PSL. Sexualidade e prevenção de IST e HIV/aids entre idosos usuários da estratégia saúde da família. Rev Prev Infecç Saúde [Internet]. 2015 [acesso em 17 set 2017];1(3):76-82. Disponível em: http://ojs.ufpi.br/index.php/nupcis/article/ view/3943/pdf

19. Ribeiro RSS, Barter B. A situação social do idoso no Brasil: uma breve consideração. Acta Paul Enferm. 2010;18(4):422-6.

20. Silva CM, Lopes FMVM, Vargens OMC. Aged woman's vulnerability related to AIDS. Rev Gaúcha Enferm. 2010;31(3):450-7.

21. Torres TL, Camargo BV, Boulsfield AB, Silva AO. Representações sociais e crenças normativas sobre envelhecimento. Ciênc Saúde Coletiva. 2015;20(12):3621-30. 
22. Moreira WC, Damasceno CKCS, Vieira SKSF, Campêlo TPT, Campêlo DS, Alencar DC. Assessment of the public policies to cope with violence against the elderly. Rev Enferm UFPE on line [Internet]. 2016 [acesso em 27 set. 2017];10(4):1324-31.

Disponível em: https://periodicos.ufpe.br/revistas/ revistaenfermagem/article/view/11120/12601
23. Moreira WC. Violência contra o idoso: uma questão de saúde pública. Reon Facema [Internet]. 2017 [acesso em 27 set. 2017];3(1):434-9. Disponível em: http://www.facema.edu.br/ojs/index.php/ ReOnFacema/article/view/186/97

24. Okuno MFP, Gomes AC, Meazzini L, Scherrer Júnior G, Belasco Júnior D, Belasco AGS. Qualidade de vida de pacientes idosos vivendo com HIV/AIDS. Cad Saúde Pública. 2014;30(7):1551-9.

Received: September 20, 2017

Reviewed: January 11, 2018

Accepted: February 08, 2018 